\title{
Extent of Collaboration among Possible Industry- Locators to a Science and Technology Park: The Case of the University of Science and Technology of Southern Philippines
}

\author{
Rhoda A. Namoco*, Elmer C. Castillano, Dennis A. Tarepe, \\ Consorcio S. Namoco Jr. and Roberto N. Padua \\ University of Science and Technology of Southern Philippines, Cagayan de Oro, Lapasan, Cagayan de Oro City, \\ Philippines; rhodaagdeppanamoco@gmail.com, elmer_castillano@yahoo.com, dennis.tarepe@yahoo.com, \\ csnamocojr@yahoo.com, robertnpadua@gmail.com
}

\begin{abstract}
Objectives: This study aimed to assess the extent of collaboration among possible partners for the proposed science and Technology Park of the University of Science and Technology of Southern Philippines. Methods: The study involved the conduct of actual visits and interviews among officials and representatives of twenty-six (26) industries located in the provinces and cities of Lanao del Norte, Bukidnon and Misamis Oriental, all in Region X, Southern Philippines. Findings: The study determined the profiles of the industry-respondents such as nature of business and their types. Inputs on possible support of these would-be industry partners around the region were also identified. These include research collaboration, involvement to curriculum development and student trainings. Application: The results of the study provide insights for crafting partnership plans to possible industry locators to Science and Technology parks.
\end{abstract}

Keywords: S\&T Parks, Industry Locators, Academe-Industry Partnerships.

\section{Introduction}

In more developed countries in the world, universities and public research laboratories are considered to be the prime movers of basic scientific researches. Industries, on the other hand, are viewed to perform the bulk of the applied research and development that is needed before new products and processes are introduced to the market. Hence, there is a need for both the academe and the industries to establish a functioning interface between these two. 1

The proposed University of Science and Technology of the Philippines (USTP) is envisioned to provide a strong link between the academe and the industries. One of the major features of the proposed USTP is the establishment of science and technology (S\&T) parks in its campuses. All over the world, the establishment of S\&T parks possesses the following characteristics: (a) the strong presence of the academe or educational research institution; (b) the provision of space for the operation of industries; (c) the opportunity for technology incubation, transfer and commercialisation; and (d) the desire to spur economic development through science and technology. $\underline{2}$

The Philippine Economic Zones (PEZs) are established to reinforce the Philippine government's efforts on investment promotion, employment creation, and export generation. Recently, the Philippine Economic Zone Authority (PEZA) ceased developing economic zones but instead, encouraged the private sectors to develop economic zones. $\underline{3}$ As of November 2017, there

${ }^{*}$ Author for correspondence 
are 381 operating economic zones which include 74 manufacturing or industrial estates, 262 information technology (IT) parks and IT centers, 22 agro-industrial economic zones, 19 tourism ecozones, and 2 medical tourism park. Moreover, there are 16 PEZA-registered public and private economic zones. $\underline{4}$

In the Philippines, PEZ provides venues for the last three characteristics of S\&T parks while the first characteristic is yet to be realized in the context of the Philippine higher education system. Hence, there is a need to entice local and foreign industries to locate themselves within the proposed S\&T parks of USTP in order to fully realize the creation of a true S\&T park in the Philippines. However, there is a need to establish policies which would provide mutual benefits between and among the academe and industry locators.

In Thailand, for example, the government established the Thailand Science Park (TSP) in Pathum Thani province in 2002 to facilitate: innovation, attract highly technologically-advanced and international companies, commercialisation of technologies, link universities and research laboratories and companies, incubate start-ups and generate employment. Industries situated in the TSP are given privileges and incentives such as accelerated depreciation rate for $\mathrm{R} \& \mathrm{D}$ machineries and equipment, import tax exemption for machineries, equipment and materials used in R\&D activities, exemption of corporate income tax for 8 years, work permit and visa for foreign researchers and experts, allowance for foreign ownership, promote joint $\mathrm{R} \& \mathrm{D}$ activities between $\mathrm{R} \& \mathrm{D}$ institute or university and industry, and tax credit $70 \%$ of $\mathrm{R} \& \mathrm{D}$ expenditure but not to exceed 10 million baht. Currently, TSP houses 61 Thai and foreign companies. Following the success of the TSP, four more science parks (considered as regional science parks) were set up to support and encourage small and medium enterprises and large corporations in the provinces to create new value on top of their existing business through research and development. These are the Northern Science Park in Chiang Mai University, Northeastern Science Park (Khonkaen University, Suranaree University of Technology, Maha Sarakham University and Ubon Rajathanee University), Eastern Science Park at Burapha University, and Southern Science Park (Prince of Songkia University, Walairak University, and Thaksin University). Thailand Institute of Scientific and Technological Research and National Science and Technology Agency (NSTDA) have been assigned operators of the 5 science parks. $\underline{5} \underline{6}$
The aim of setting up of science parks in Thailand is to build places where researchers and the private sectors can work together on research and development and transfer knowledge for the main purpose of developing technology for commercial use. The move is to provide support that meets the specific needs of local industries in each region. The four Regional Science Parks are university-based and are also supported by the Thai government. One of the universities under the Northeastern Science Park cluster is the Suranaree University, located in Nakhon Ratchasima, Thailand's largest province situated on sprawling northeast plateau. It is located approximately 260 kilometers northeast of Bangkok. It covers an area of 25,494 square kilometers that is mainly plateaus and mountainous terrain. Suranaree University of Technology (SUT) Science Park is an academic center for promoting the quality of livelihood in the community and enhancing the industries and service businesses in the northeastern region. Through the use of science and technology, the park elevates its manufacturing potential with an aim of increasing the standard quality and value of products while increasing competing performance and helping to sustainably develop the community.Technologydevelopment activities related to software, automotive, agriculture, and silk industries are some of the R\&D activities being conducted by SUT Science Park.

Based on the experiences of Thailand, which operates university-based science parks, there is a clear mutual benefit between industries and the academe. This study aimed to determine the extent of collaboration among would-be industry-locators to the proposed USTP Science Parks.

This study is organized as follows: Section 1 presents a brief introduction of the study. Methodology is presented in Section 2, and section 3 presents the results. A brief conclusion is given in Section 4.

\section{Methodology}

In order to obtain profiles of industries, a list of existing industries in the areas of Misamis Oriental, Lanao del Norte, Cagayan de Oro and Bukidnon areas were obtained through visits in government and non-governmental organisations. After a list of all the industries around the area were obtained, letters requesting for appointments to visit these industries were then sent. After appointments were confirmed, actual visits to these industries were 
done in order to conduct personal interviews using the survey questionnaires developed for this study.

In cases when these industries do not allow the team to do personal interviews, survey questionnaires were sent through their security officers and/or human resource (HR) officer. Thorough follow-ups are then made in order to be able to retrieve these survey questionnaires.

A total of twenty-six (26) industries were included in this study. During the industry visits, the research teams were also given the chance to go around the industry premises to see some of the processes that take place in these industries.

\section{Results}

The survey results provide profiles of industries around the provinces of Misamis Oriental, Cagayan de Oro, Lanao del Norte and Bukidnon, Philippines. It should be noted that not all industries were visited due to various reasons such as non-availability of industry head for the interview, inaccessibility of industry location, among others. Classifications and types of industries visited were made based on survey results. Results are summarized on Table 1.

It can be seen from Table 1 that a number of the industries visited belong to the manufacturing industry. Results also show that the industries included in the survey are industries which are considered as the main drivers of economic growth in the Philippines. ${ }^{?}$

The industries visited are also categorized according to their business type. This is summarized in Table 2. It can

Table 1. Summary of industries visited based on classification

\begin{tabular}{|l|l|}
\hline Classification of industry & $\begin{array}{l}\text { Number of } \\
\text { industries }\end{array}$ \\
\hline Agriculture, forestry and fishing & 3 \\
\hline Manufacturing & 14 \\
\hline $\begin{array}{l}\text { Electricity, gas, steam and air-conditioning } \\
\text { supply and water supply }\end{array}$ & 2 \\
\hline $\begin{array}{l}\text { Water supply, sewerage, waste management } \\
\text { and remediation activities }\end{array}$ & 1 \\
\hline Construction & 2 \\
\hline $\begin{array}{l}\text { Wholesale and retail trade; repair of motor } \\
\text { vehicles and motorcycles }\end{array}$ & 1 \\
\hline Information and communication & 4 \\
\hline Metal fabrication & 1 \\
\hline
\end{tabular}

Table 2. Type of business of industries visited

\begin{tabular}{|l|l|}
\hline Business type & Number of industries \\
\hline Corporation and partnership & 23 \\
\hline $\begin{array}{l}\text { Single proprietorship with } \\
\text { branches }\end{array}$ & 1 \\
\hline Family business & 2 \\
\hline
\end{tabular}

Table 3. Extent of support to S\&T parks from industries

\begin{tabular}{|l|l|}
\hline Extent of support & $\begin{array}{l}\text { Number of } \\
\text { industries }\end{array}$ \\
\hline Training of students & 25 \\
\hline $\begin{array}{l}\text { Participation in curriculum } \\
\text { development }\end{array}$ & 11 \\
\hline Involvement in research undertakings & 11 \\
\hline $\begin{array}{l}\text { Conduct of corporate social } \\
\text { responsibility-related research }\end{array}$ & 2 \\
\hline
\end{tabular}

be seen that most of these industries are corporations. In fact, most of these industries have branches in other parts of the country.

Moreover, the extent of support that these industries can give to the proposed USTP science and technology park was also identified. This is summarized in Table 3. It can be seen that almost all industries visited are willing to partner with USTP in training students.

This is supportive of the main objective of the science and technology parks which is to bring the world of work to the classroom. Some industries would also want to be involved in enhancing the curriculum to ensure that students are trained according to the needs of the industries.

\section{Conclusion}

In this study, a total of 26 industries were visited. Profiles of these industries were then obtained. Moreover, the extent of partnerships that these industries can provide was also identified. Survey results show that 11 industries may agree to establish long-term ties with the proposed USTP Science Park in order to conduct research, be a venue for student and faculty trainings and provide inputs for curriculum development. About 25 industries, on the other hand, may allow partnership in terms of providing training to students, while 2 industries visited 
may offer partnership in terms of conducting corporate social responsibility-related research.

\section{References}

1. Update on PEZA activities and programs. [cited $2011 \mathrm{Feb}$ 16]. http://www.investphilippines.info/arangkada/updateon-pezas-activities-and-programs/.

2. University-industry research partnerships in the United States. [cited 2004]. https://eml.berkeley.edu/ bhhall/ papers/BHH\%20Kansai2002.pdf.

3. University-industry linkages in Thailand: successes, failures and lessons learned for other developing countries. [cited 2009]. https://smartech.gatech.edu/handle/1853/34909.
4. Multi-year expert meeting on enterprise development policies and capacity-building in science, technology and innovation. [cited 2009 Jan 20]. https://unctad.org/en/ Pages/MeetingsArchive.aspx? meetingid $=15864$.

5. Gross domestic product of the Philippines highlights for 2018. [cited 2019 Apr 25]. https://psa.gov.ph/grdp/ highlights.

6. PhilippineEconomicZone Authority(PEZA). [cited2017Nov 30]. http://www.peza.gov.ph/index.php/economic-zones/ list-of-economic-zones/operating-economic-zones.

7. Philippines: a science nation meeting global challenges. [cited 2014]. http://www.keepcalmandposters.com/poster/ 4917290_philippines_a_science_nation_meeting_global_ challenges_through_environmental_challeng. 